\title{
STUDIES ON THE EXPLOITATION OF TRENCHED SARDINE AMBLYGASTER SIRM (WALBAUM) OFF THE NEGOMBO COAST
}

\author{
W.P.N KARUNASINGHE ${ }^{1}$ and M.J.S. WIJEYARATNE ${ }^{2}$ \\ 1 National Aquatic Resources Agency, Crow Island, Colombo 15. \\ 2 Department of Zoology, University of Kelaniya, Kelaniya.
}

(Received: 12 August 1992; accepted: 14 January 1995)

\begin{abstract}
Amblygastersirm (Family: Clupeidae) constitutes $>40 \%$ of the small pelagic fish production in the western coastal waters of Sri Lanka. Using the catch and effort statistics from 1980 to 1981 and from 1983 to 1988 , the maximum sustainable yield and optimum fishing effort for this species were calculated to be $3512.39 \mathrm{mt} /$ year and 337 boats/day respectively. To optimally exploit fishery, the size at first capture of $A$. sirm should be maintained at $16.00 \mathrm{~cm}$ total length and gill nets with a stretched mesh size of over $2.5 \mathrm{~cm}$ have to be used. At present, $A$ : sirm appears to be heavily over-exploited.
\end{abstract}

Key words: Amblygaster sirm, maximum sustainable yield.

\section{INTRODUCTION}

Amblygaster sirm (Family: Clupeidae) dominates fish catches in the west coast of Sri Lanka throughout the year. ${ }^{1}$ It is frequently found in the catches of gill nets and purse seines and occasionally in beach seines operated at a depth range of $5-70 \mathrm{~m} .{ }^{2}$ Recent statistics indicate that this species constitutes $>40 \%$ of the small pelagic fish production in the west coast of Sri Lanka. ${ }^{3}$ In the small meshed gill nets operated in this region, A. sirm is observed to be the most abundant species. ${ }^{4}$ These gill nets, with mesh sizes ranging from $2.3 \mathrm{~cm}$ to $3.8 \mathrm{~cm}$ stretched mesh, are mostly operated by $5-7 \mathrm{~cm}$ fibre reinforced plastic boats powered by $10-25 \mathrm{hp}$ out-board engines. ${ }^{5}$ In the recent past, some studies on the status of the gill net fishery of A. sirm in Sri Lanka have been carried out. These include investigations on craft and gear, catch and effort statistics, ${ }^{4,6}$ growth parameters, ${ }^{7}$ selectivity patterns ${ }^{5,7,8}$ length frequency distributions, mortalities ${ }^{1,5,6,7}$ and yield per recruit isopleths. ${ }^{1}$

However information on the maximum sustainable yield, optimum fishing effort and optimum size at first capture of this species in Sri Lanka are not available. This paper deals with (a) the effects of changing the size at first capture, (b) maximum sustainable yield and (c) optimum fishing effort; for $A$. sirm in the small meshed gill net fishery in the west coast of Sri Lanka.

\section{METHODS AND MATERIALS}

Sampling of the catch was carried out once a week at the fish landing site at Negombo for a period of four years from September 1984 to August 1988 (Fig. 1). On each sampling day, total number of boats operating gill nets for $A$. sirm was recorded and 5\% of them were randomly selected for the collection of detailed statistics on catch and effort. The catch and effort statistics were used in

* Corresponding author. 
Schaefer's surplus yield model ${ }^{9}$ to estimate the maximum sustainable yield and optimum effort. The catch and effort statistics collected by Siddeek et al. ${ }^{6}$ in $1980 / 81$, and 1983/84 were also used. Beverton and Holt's yield per recruit model $^{10}$ was used to estimate the relative yield per recruit at different sizes of first capture and at different exploitation rates. In this analysis, the values used for natural mortality coefficient and growth coefficient were 1.30 year $^{-1}$ and 1.25 year $^{-1}$ respectively. ${ }^{\text {? }}$
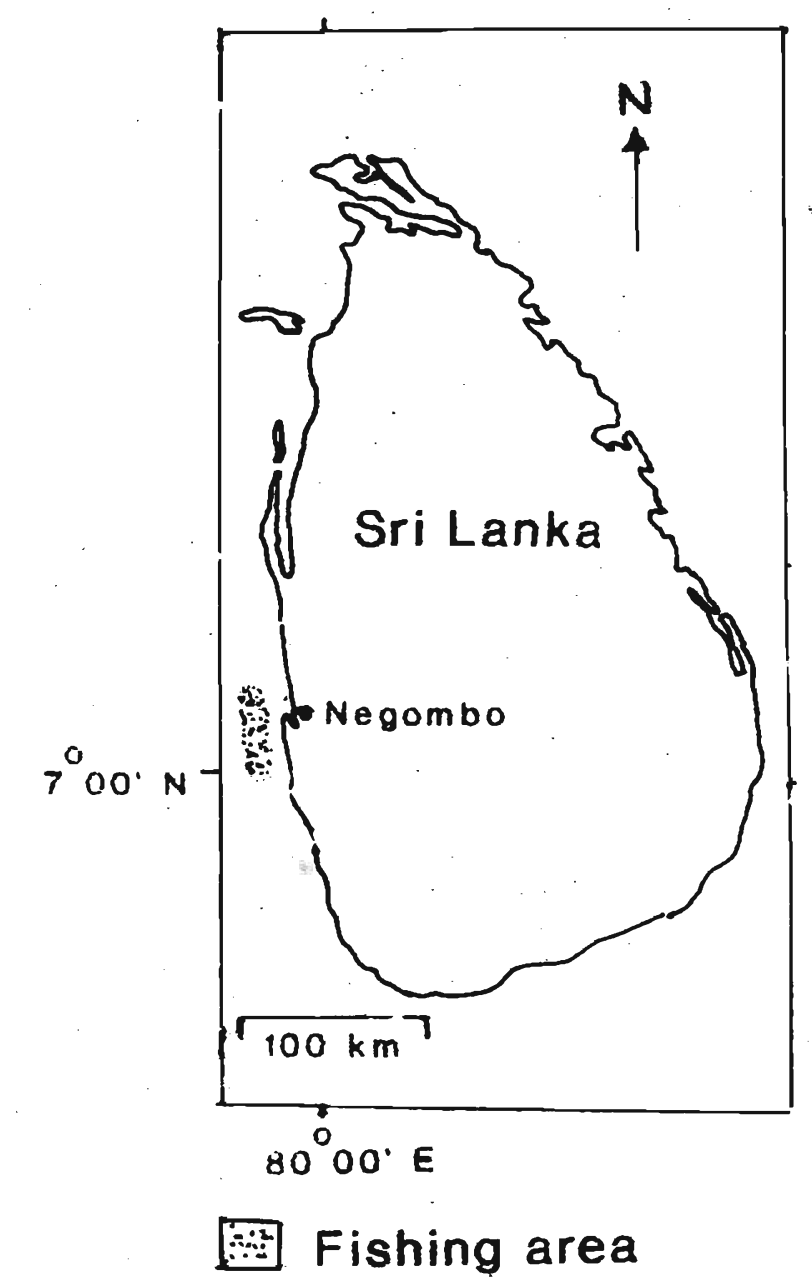

Figure 1: Fishing area and the landing site.

\section{RESULTS}

The catch and effort statistics of $A$. sirm in the coastal waters around Negombo during the study period are summarized in Table 1.

The monthly variation of yield, fishing effort and catch per unit effort (CPUE) during the study period are shown in Figure 2. 

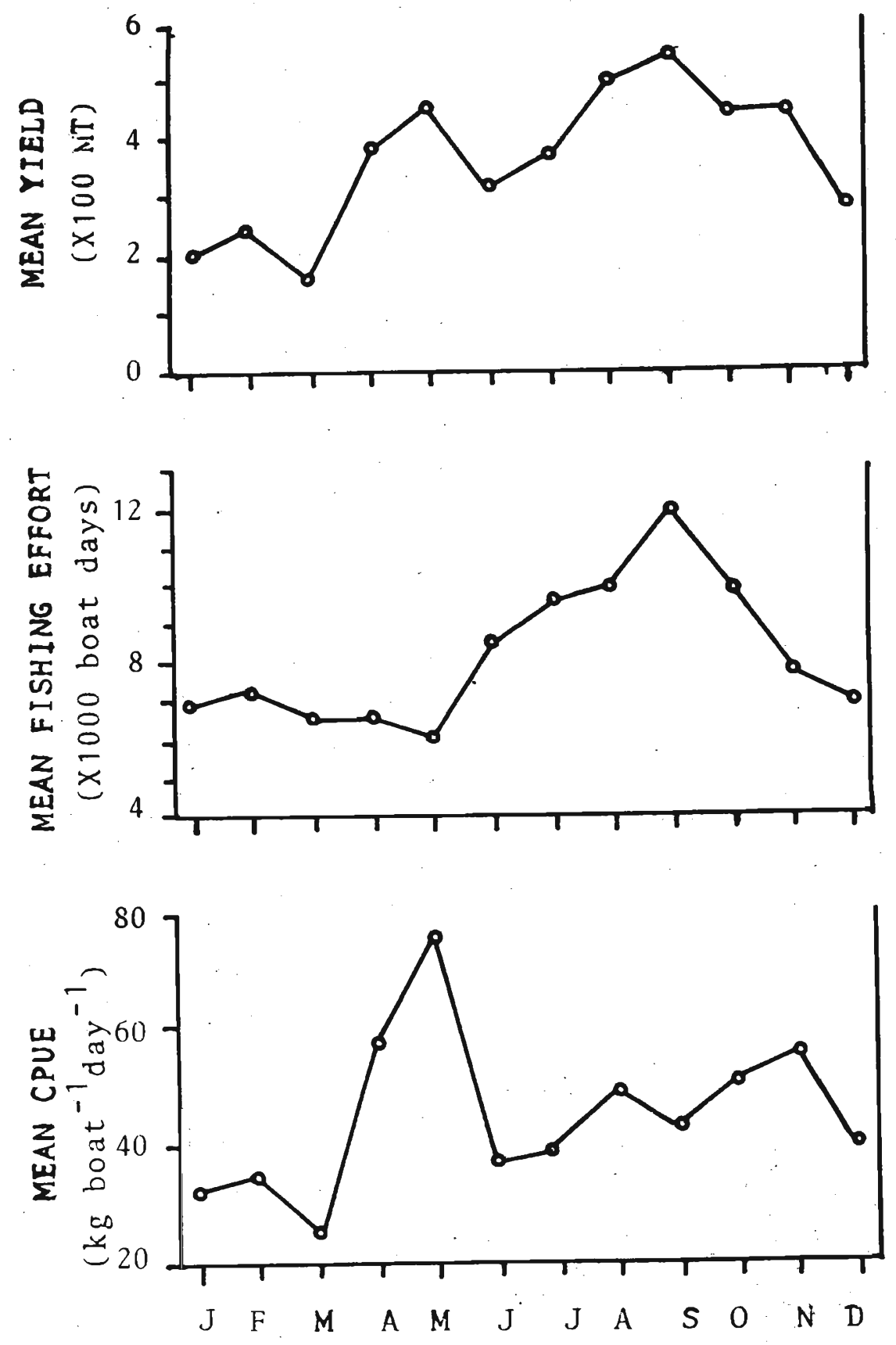

Figure 2: Monthly variation of the yield, fishing effort and CPUE of A. sirm fishery during the study period. 
Table 1: Catch and effort statistics of A. sirm fishery in the coastal waters around Negombo.

\begin{tabular}{ccccc}
\hline Year & $\begin{array}{c}\text { Annual yield } \\
(\mathrm{mt})\end{array}$ & $\begin{array}{c}\text { Mean no.of } \\
\text { boats operated } \\
\text { daily }\end{array}$ & $\begin{array}{c}\text { Annual } \\
\text { effort } \\
\text { (boat days) }\end{array}$ & $\begin{array}{c}\text { Catch per } \\
\text { unit effort (CPUE) } \\
\left(\mathrm{kg} \mathrm{boat}^{-1} \text { day }^{-1}\right)\end{array}$ \\
\hline 1984 & 3497.6 & 444 & 117370 & 29.8 \\
1985 & 3533.3 & 547 & 144510 & 24.5 \\
1986 & 2469.3 & 407 & 107595 & 23.0 \\
1987 & 2921.5 & 407 & 107488 & 27.2 \\
1988 & 4907.0 & 377 & 99615 & 49.3 \\
\hline
\end{tabular}

The results of the analysis carried out using Schaefer's model are summarized in Table 2.

Table 2: Results of the analysis of catch and fishing effort using Schaefer's model.

\begin{tabular}{ll}
\hline Intercept of the regression line & 79.07 \\
Slope of the regression line & $-4.45 \times 10^{-4}$ \\
Correlation coefficient & 0.83 \\
n & 6 \\
Level of significance & $<0.05$ \\
Optimum effort (boats day $\left.{ }^{-1}\right)$ & 336 \\
Maximum sustainable yield (mt year-1) & 3512.4 \\
\hline
\end{tabular}

The variation patterns of relative yields per recruit with exploitation rate for different sizes at first capture are shown in Figure 3 . It is evident that at the optimum exploitation rate of $0.5,{ }^{11}$ the maximum yield per recruit is obtained when the size at first capture is $16.0 \mathrm{~cm}$.

\section{DISCUSSION}

Results show that the annual yield, fishing effort and catch per unit effort varied markedly during the study period. The increased catch observed in 1985 could be mainly attributed to the increased fishing effort in this year. The increased fishing effort observed in 1985 is probably due to the influx of fishermen from the northern and eastern regions of the island subsequent to the $1983 / 84$ communal disturbances. Apart from the variation of fishing effort, several other biological and social factors affect the small scale fisheries in most developing countries. ${ }^{12}$

Competition from other fisheries which use more efficient gear for the same stock is a problem faced by small scale fisheries. No beach seines operated and purse seines were prohibited in this region during the study period. However in 1986, a few purse seines were observed to illegally operate in the coastal waters 
off Negombo and these may have caught considerable amounts of trenched sardines. ${ }^{13}$ 'The decrease in catch per unit effort (CPUE) of $A$. sirm from gill nets observed in 1986 may be due to the operation of the purse seines. Therefore, in the management of this fishery it is necessary to take steps to stop the encroachment by vessels operating more efficient types of gear such as purse seines.

Analysis carried out using the Schaefer's model indicates that the optimum fishing effort is less than the present level. Therefore, the mean number of boats operated daily need to be decreased to about 337 for sustainable exploitation of A. sirm in this region.

The results show that from November to May, the mean number of boats operated daily is less than the optimum. However, despite the lower fishing effort the catch was observed to be high in April, May and November. Therefore, it appears that the fishing effort could be increased in these months and be reduced in months such as June, July and September in which the CPUE is low. In addition, since the catch is low from December to March, the fishing effort in these months could also be reduced. In this way, the number of boats operated daily can be reduced to the optimum. In order to minimize unemployment consequent to reduced fishing of $A$. sirm, it is recommended that fishing in deep sea and off-shore regions is encouraged.

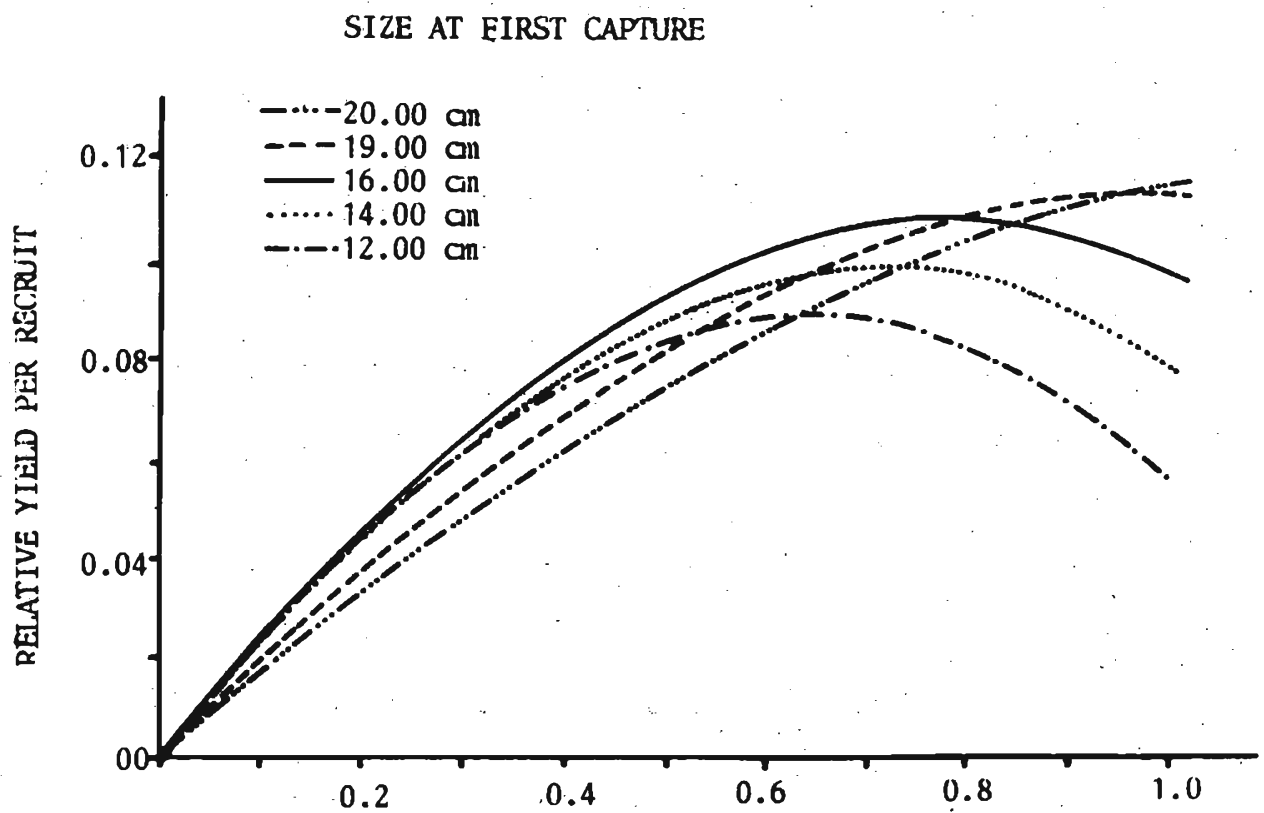

EXPLOITATION RATE

Figure 3: Variation of relative yield per recruit with exploitation rate for different sizes at first capture. 
Studies on the selectivity patterns of the gill nets operated for $A$. sirm indicate that gill nets of mesh sizes above $2.7 \mathrm{~cm}$ stretched mesh have an optimum selection length $>16.0 \mathrm{~cm}$. The actual mesh sizes of gill nets used for A. sirm fishery varied from $2.3 \mathrm{~cm}$ to $3.8 \mathrm{~cm} .^{5}$ Therefore, for a sustainable exploitation of this fishery resource, it is necessary to discourage the use of gill nets that have mesh sizes $<2.7 \mathrm{~cm}$ stretched mesh.

\section{Acknowledgement}

The authors thank the Chairman and Director-General of the National Aquatic Resources Agency for providing facilities to carry out this research.

\section{References}

1. Dayaratne P. (1985). Status of the sardine stocks on the west coast of Sri Lanka. Journal of National Aquatic Resources Agency, Sri Lanka 32 (1,2): 147-150.

2. Karunasinghe W.P.N. \& Dayaratne P. (1986). Small pelagic fisheries in the west and south coasts of Sri Lanka. Proceedings of the Sri Lanka Association for the Advancement of Science. (Abstract) 42(1): 229.

3. Dayaratne P. (1984). Fisheries biology of some small pelagic fish species (Clupeoides) from the west coast of Sri Lanka. University of Bergen, Norway. $\mathrm{Ph}$. D. thesis.

4. Karunasinghe W.P.N. \& Fonseka M. (1985). A preliminary analysis of small mesh gill net fishery in the inshore waters of Sri Lanka. Journal of National Aquatic Resources Agency, Sri Lanka 32(1,2): 25-34.

5. Karunasinghe W.P.N. \& Wijeyaratne M.J.S. (1991). Selectivity estimates for Amblygaster sirm (Clupeidae) in the small meshed gill net fishery on the west coast of Sri Lanka. Fisheries Research 10: 199-205.

6. Siddeek M.S.M., Joseph L., Jayasuriya P.M.A. \& Karunasinghe W.P.N. (1985). A preliminary analysis of length frequency data of Amblygaster sirm from Negombo, Sri Lanka using ELEFAN programmes. Journal of National Aquatic Resources Agency, Sri Lanka 32(1,2): 46-56.

7. Karunasinghe W.P.N. \& Wijeyaratne M.J.S. (1991). Population dynamics of Trenched sardine Amblygaster sirm (Clupeidae) in the western coastal waters of Sri Lanka. Asian Fisheries Science 4: 329-334.

8. Dayaratne P. (1988). Gill net selectivity for Amblygaster (=Sardinella) sirm. Asian Fisheries Science 2: 71-82.

9. Pauly D. (1984). Fish population dynamics in tropical waters: A manual for use with programmable calculators. ICLARM studies and reviews. 8: 1-325, ICLARM, Philippines. 
10. Beverton R.J.H. \& Holt S.J. (1964). Table of yield functions for fishery manage ment, FAO Fisheries Technical Paper 38: 1-49, FAO, Rome.

11. Gulland J.A. (1975). Manual of methods for fish stock assessment: part 1fish population analysis, 1-154, FAO, Rome.

12. Panayotou T. (1982). Management concepts for small scale fisheries: economic and social aspects. FAO Fisheries Technical Paper 228: 1-53, FAO, Rome, Italy.

13. Karunasinghe W.P.N. (1990). Some aspects of biology and fishery of trenched sardine. Amblygaster sirm (Pisces : Clupeidae) from the coastal waters around Negombo, Sri Lanka. M. Phil. Thesis. University of Kelaniya, Sri Lanka. 